\title{
Manufacturing and Applications of Stainless Steels
}

\author{
Andrea Di Schino \\ Dipartimento di Ingegneria, Università di Perugia, Via G. Duranti, 06125 Perugia, Italy; \\ andrea.dischino@unipg.it
}

Received: 24 February 2020; Accepted: 26 February 2020; Published: 1 March 2020

\section{Introduction and Scope}

Stainless steels represent quite an interesting material family, both from a scientific and commercial point of view, owing to their excellent qualities in terms of strength and ductility, combined with corrosion resistance. Thanks to such properties, stainless steels have been indispensable for technological progress during the last century and their annual consumption has increased faster than other materials. They find application in all fields requiring materials with good corrosion resistance, together with the ability to be worked into complex geometries. Despite their diffusion as a consolidated material, many research fields are active regarding the possibility of increasing stainless steel's mechanical properties and corrosion resistance by grain refinement or alloying by interstitial elements. At the same time, innovations are coming from the manufacturing process of the stainless steel family of materials, including the possibility to manufacture them from metal powder for 3D printing. The scope of this Special Issue embraces interdisciplinary work covering physical metallurgy and processes, reporting about experimental and theoretical progress concerning microstructural evolution during processing, microstructure-properties relationships and various applications, including automotive, energy and structural.

\section{Contributions}

The book collects manuscripts from academic and industrial researchers with stimulating new ideas and original results. It consists of four review and ten research papers. The review papers focus on the state of the art and perspectives in repairing and reinforcing historic timber structures by stainless steels [1], on duplex and super-duplex stainless steel microstructures and the evolution of their properties by surface modification processes [2], on the process and properties of reversion-heated austenitic stainless steels [3] and on the 3D printing of stainless steels by the laser powder bed fusion technique [4]. A group of research papers deal with physical metallurgy and advancedcharacterization techniques [5], others with process aspects [6-8] or property application items related to stainless steels [9-14]. The paper by Fava et al. [5] presents and discusses the results of mechanical spectroscopy tests carried out on $\mathrm{Cr}$ martensitic steel. The study regards the following topics: (i) embrittlement induced by $\mathrm{Cr}$ segregation; (ii) the interaction of hydrogen with $\mathrm{C}-\mathrm{Cr}$ associates; (iii) the nucleation of $\mathrm{Cr}$ carbides. This technique permitted the authors to characterize the specific role played by point defects in the investigated phenomena. Due et al. [6] investigate non-metallic inclusions in 316L stainless steel bars with and without $\mathrm{Ca}$ treatments. The inclusions are extracted using electrolytic extraction. After that, the characteristics of the inclusions, such as morphology, size, number, and composition, are investigated by using a scanning electron microscope in combination with energy-dispersive $\mathrm{X}$-ray spectroscopy. Chen et al. [7] report the formation and characteristics of non-metallic inclusions in 304L stainless steel during the vacuum oxygen decarburization refining process, using industrial experiments and thermodynamic calculations. The compositional characteristics indicated that two types of inclusions with different sizes (from 1 to $30 \mu \mathrm{m}$ ) existed in 304L stainless steel during the refining process, i.e., $\mathrm{CaO}-\mathrm{SiO} 2-\mathrm{Al} 2 \mathrm{O} 3-\mathrm{MgO}$ external inclusions, and $\mathrm{CaO}-\mathrm{SiO} 2-\mathrm{Al} 2 \mathrm{O} 3-\mathrm{MgO}-\mathrm{MnO}$ 
endogenous inclusions. Luu et al. [8] analyze the post-annealing mechanical behavior of 316L austenitic stainless steel (SUS316L) after electrically assisted annealing with a single pulse of electric current and evaluated the feasibility of a two-stage forming process of the selected SUS316L with rapid electrical assisted annealing. Peng et al. [9] report an experimental data assessment and fatigue design recommendation for stainless steel welded joints. Juuti et al. [10] present a new family of ferritic stainless steels for service temperatures up to $1050{ }^{\circ} \mathrm{C}$, utilizing intermetallic phase transformation. Cianetti et al. [11] report a novel method for the evaluation of the surface fatigue strength of a stainless steel component. The proposed approach is a hybrid method, numerical-theoretical, which allows us to estimate the surface fatigue strength in a very short time without having to resort to finite element models that often are so complex that they starkly contrast industrial purposes. Prosviryakov et al. [12] present a novel corrosion-resistant steel with a high boron content. The positive influence of $\mathrm{Zr}$ addition on the microstructure and mechanical properties after hot deformation is shown. The $\mathrm{Zr}$-alloyed steel demonstrates hot deformation without fracturing in the temperature range of 1273-1423 K, and in the strain rate range of $0.1-10 \mathrm{~s}^{-1}$, despite the high volume of brittle borides. Gennari et al. [13] present a paper about the microstructural and corrosion properties of cold-rolled laser-welded UNS S32750 duplex stainless steel. Zhang et al. [14] report the temperature dependence of phase transformation kinetics during tempering in $13 \mathrm{Cr}$ super-martensitic stainless steel.

Acknowledgments: As Guest Editor, I would like to especially thank Kinsee Guo, Assistant Editor, for his support and active role in the publication. I am also grateful to the entire staff of the Metal Editorial Office for the precious collaboration. Last but not least, I wish to express my gratitude to all the contributing authors and reviewers: without your excellent work, it would not have been possible to accomplish this Special Issue that I hope will be a piece of interesting reading and reference literature.

Conflicts of Interest: The author declares no conflict of interest.

\section{References}

1. Corradi, M.; Osoforo, A.I.; Borri, A. Repair and reinforcement of historic timber structures with stainless steel-A review. Metals 2019, 9, 106. [CrossRef]

2. Tahchieva, A.B.; Llorca-Isern, N.; Cabrera, J.M. Duplex and super duplex stainless steels: Microstructure and property evolution by surface modification processes. Metals 2019, 9, 347. [CrossRef]

3. Järvenpää, A.; Jaskari, M.; Kisko, A.; Karjalainen, P. Process and properties of reversion-treated austenitic stainless steels. Metals 2020, 10, 281. [CrossRef]

4. Zitelli, C.; Folgarait, P.; Di Schino, A. Laser powder bed fusion of stainless steel grades: A review. Metals 2019, 9, 731. [CrossRef]

5. Fava, A.; Montanari, R.; Varone, A. Mechanical spectroscopy investigation of point defect-driven phenomena in a Chromium martensitic steel. Metals 2018, 8, 870. [CrossRef]

6. Du, H.; Karasev, A.; Sundqvist, O.; Jonsson, P. Modification of non-metallic inclusions in stainless steels by addition of CaSi. Metals 2019, 9, 74. [CrossRef]

7. Chen, X.; Cheng, G.; Li, J.; Hou, Y.; Pan, J.; Ruan, Q. Characteristic and formation mechanism of inclusions in 304L stainless steel during the VOD refining process. Metals 2018, 8, 1024. [CrossRef]

8. Luu, V.T.; Nguyen, T.A.N.; Hong, S.T.; Jeong, H.J.; Han, H.N. Feasibility of a two stage forming process of a 316L austenitic stainless steel with rapid electrically assisted annealing. Metals 2018, 8, 815. [CrossRef]

9. Peng, Y.; Chen, J.; Dong, J. Experimental data assessment and fatigue design recommendation for stainless steel welded joints. Metals 2019, 9, 723. [CrossRef]

10. Juuti, T.; Manninen, T.; Uusikallio, S.; Komi, J.; Porter, D. New ferritic stainless steels for service temperatures up to $1050{ }^{\circ} \mathrm{C}$ utilizing intermetallic phase transformation. Metals 2019, 9, 664. [CrossRef]

11. Cianetti, F.; Ciotti, M.; Palmieri, M.; Zucca, G. On the evaluation of surface fatigue strength of stainless steel aeronautical component. Metals 2019, 9, 455. [CrossRef]

12. Prosviryakov, A.; Mondoloni, B.; Churyumov, A.; Pozdniakov, A. Microstrcture and hot deformation behavior of a novel Zr-alloyed high-Boron steel. Metals 2019, 9, 218. [CrossRef] 
13. Gennari, C.; Lago, M.; Bogre, B.; Meszaros, I.; Calliari, I.; Pezzato, L. Microstructural and corrosion properties of cold rolled laser welded UNS S32750 duplex stainless steel. Metals 2018, 8, 1074. [CrossRef]

14. Zhang, Y.; Yin, Y.; Li, D.; Ma, P.; Liu, Q.; Yuan, X.; Li, S. Temperature dependent phase transformation kinetics of reverted austenite during tempering in 13Cr supermartensitic stainless steel. Metals 2019, 9, 1203. [CrossRef] 